\title{
GAO Report on Arctic Capabilities
}

DOD Addressed Many Specified Reporting Elements in Its 2011 Arctic Report but Should Take Steps to Meet Near- and Long-term Needs *

\section{Highlights}

\section{Why GAO Did This Study}

The gradual retreat of polar sea ice, combined with an expected increase in human activity - shipping traffic, oil and gas exploration, and tourism in the Arctic region - could eventually increase the need for a U.S. military and homeland security presence in the Arctic. As a result, the Department of Defense (DOD) must begin preparing to access, operate, and protect national interests there. House Report 111-491 directed DOD to prepare a report on Arctic Operations and the Northwest Passage, and specified five reporting elements that should be addressed. House Report 112-78 directed GAO to review DOD's report. GAO assessed the extent to which 1) DOD's Report to Congress on Arctic Operations and the Northwest Passage (Arctic Report) addressed the specified reporting elements and 2) DOD has efforts under way to identify and prioritize the capabilities needed to meet national security objectives in the Arctic. GAO analyzed DOD's Arctic Report and related documents and interviewed DOD and U.S. Coast Guard officials.

\section{What GAO Recommends}

GAO recommends that DOD develop a risk-based investment strategy and timeline for developing Arctic capabilities needed in the near-term; and establish a forum with the Coast Guard to identify collaborative Arctic capability investments over the long-term. DOD and the Department of Homeland Security generally agreed with GAO's recommendations.

\section{Main Findings}

DOD's Arctic Report, submitted May 31, 2011, addressed three and partially addressed two of the elements specified in the House Report, as shown in Table 1.

\footnotetext{
The report under the title "Arctic Capabilities: DOD Addressed Many Specified Reporting Elements in Its 2011 Arctic Report but Should Take Steps to Meet Near- and Long-term Needs" (GAO-12-180) was presented to the relevant committees in the U.S. Congress by the United States Government Accountability Office in January 2012. The full text of the original report is available at www.gao.gov/products/GAO-12-180.
} 
Table 1: Extent to Which DOD's Arctic Report Addressed the Five Specified Reporting Elements

\section{Specified reporting element}

An assessment of the strategic national security objectives and restrictions in the Arctic region.

An assessment on mission capabilities required to support the strategic national security objectives and a timeline to obtain such capabilities.

An assessment of an amended unified command plan that addresses opportunities of obtaining continuity of effort in the Arctic Ocean by a single combatant commander.

An assessment of the basing infrastructure required to support Arctic strategic objectives, including the need for a deep-water port in the Arctic.

An assessment of the status of and need for icebreakers to determine whether icebreakers provide important or required mission capabilities to support Arctic strategic national security objectives, and an assessment of the minimum and optimal number of icebreakers that may be needed.

\section{GAO assessment}

Addressed

Partially addressed (does not include a timeline for obtaining needed capabilities)

Addressed

Addressed

Partially addressed (does not include an assessment of the minimum and optimal

Source: GAO analysis of DOD's Arctic Report.

While DOD has undertaken some efforts to assess the capabilities needed to meet national security objectives in the Arctic, it is unclear whether DOD will be in a position to provide needed capabilities in a timely and efficient manner because it lacks a risk-based investment strategy for addressing near-term needs and a collaborative forum with the Coast Guard for addressing long-term capability needs. DOD's Arctic Report acknowledges that it has some near-term gaps in key capabilities needed to communicate, navigate, and maintain awareness of activity in the region. However, DOD has not yet evaluated, selected, or implemented alternatives for prioritizing and addressing near-term Arctic capability needs. In addition, DOD and the Coast Guard have established a working group to identify potential collaborative efforts to enhance U.S. Arctic capabilities. This working group is focused on identifying potential nearterm investments but not longer-term needs, and it is currently expected to be dissolved in January 2012. Uncertainty involving the rate of Arctic climate change necessitates careful planning to ensure efficient use of resources in developing Arctic needs such as basing infrastructure and icebreakers, which require long lead times to develop and are expensive to build and maintain. Without taking steps to meet near- and long-term Arctic capability needs, DOD risks making premature Arctic investments, being late in obtaining needed capabilities, or missing opportunities to minimize costs by collaborating on investments with the Coast Guard. 


\section{Arctic Capabilities}

The gradual retreat of polar sea ice in the Arctic region, combined with an expected increase in human activity - shipping traffic, oil and gas exploration, and tourism - could eventually increase the need for a U.S. military and homeland security presence in the Arctic. ${ }^{1}$ In recognition of increasing strategic interest in the Arctic, the United States has developed national level policies that guide the actions of the Department of Defense (DOD), the U.S. Coast Guard, and other stakeholders in the region. These policies indicate that the United States has an enduring interest in working collaboratively with other nations to address the emerging challenges arising from the impacts of climate change and globalization in the Arctic, and they identify Arctic national security needs including protecting the environment, managing resources, and supporting scientific research. ${ }^{2}$

Over the years, we have completed a number of reviews related to the challenges of developing capabilities for operating in the Arctic. For example, we have reported on the difficulties DOD and other agencies face in achieving maritime domain awareness. ${ }^{3}$ We testified on the challenges of translating climate data into information that officials need to make decisions. ${ }^{4}$ We also reported on the Coast Guard's coordination with stakeholders on Arctic policy and efforts to identify Arctic requirements and capability gaps. ${ }^{5}$ A list of these related products is included at the end of this report.

In light of continuing concerns, the House Armed Services Committee directed DOD to provide a report to the congressional defense committees on its Arctic operations in the House Report accompanying a proposed bill for the National Defense Authorization Act for Fiscal Year 2011 (H.R. 5136). ${ }^{6}$ Specifically, DOD was directed to address five elements in the report, including an assessment of (1) the strategic national

1 The DOD Report to Congress on Arctic Operations and the Northwest Passage defines the Arctic as the region that encompasses all U.S. and foreign territory north of the Arctic Circle, all U.S. territory north and west of the boundary formed by the Porcupine, Yukon, and Kiskokwim Rivers, and all contiguous seas and straits north of and adjacent to the Arctic Circle. According to the report, this definition is consistent with the Arctic Research and Policy Act of 1984 (15 U.S.C. §4111) and Arctic Council usage.

2 National Security Presidential Directive 66/Homeland Security Presidential Directive 25, Arctic Region Policy (9 January 2009); National Security Strategy (Washington, D.C.: May 2010).

3 GAO, Intelligence, Surveillance, and Reconnaissance: DOD Needs a Strategic, Risk-Based Approach to Enhance Its Maritime Domain Awareness, GAO-11-621 (Washington, D.C.: 20 June 2011). According to DOD's Arctic Report, maritime domain awareness refers to the effective understanding of anything associated with maritime activity that could affect the security, safety, economy, or environment of the United States.

4 GAO, Climate Change Adaptation: Federal Efforts to Provide Information Could Help Government Decision Making, GAO-12-238T (Washington, D.C.: 16 November 2011).

5 GAO, Coast Guard: Efforts to Identify Arctic Requirements Are Ongoing, but More Communication about Agency Planning Efforts Would Be Beneficial, GAO-10-870 (Washington, D.C.: 15 September 2010).

6 H.R. Rep. No. 111-491, at 337 (2010). 
security objectives and restrictions in the Arctic region; (2) mission capabilities required to support the strategic national security objectives and a timeline to obtain such capabilities; (3) an amended unified command plan that addresses opportunities of obtaining continuity of effort in the Arctic Ocean by a single combatant commander; (4) the basing infrastructure required to support Arctic strategic objectives, including the need for a deep-water port in the Arctic; and (5) the status of and need for icebreakers to determine whether icebreakers provide important or required mission capabilities to support Arctic strategic national security objectives and an assessment of the minimum and optimal number of icebreakers that may be needed. DOD submitted its Report to Congress on Arctic Operations and the Northwest Passage (Arctic Report) on May 31, 2011.

House Report 112-78, which accompanied a proposed bill for the National Defense Authorization Act for Fiscal Year 2012 (H.R. 1540), directed us to provide an assessment of DOD's Arctic Report, any shortfalls noted, recommendations for legislative action, and any information deemed appropriate in the context of the review to the congressional defense committees within 180 days of receiving DOD's Arctic Report. ${ }^{7}$ Specifically, our objectives are to assess the extent to which (1) DOD's Arctic Report addressed the specified reporting elements and (2) DOD has efforts under way to identify and prioritize the capabilities needed to meet national security objectives in the Arctic. This letter and Appendix II provide our response to the direction in the house report and include an assessment of the degree to which DOD addressed each of the five specified reporting elements in its report provided to the defense committees.

To assess the extent to which DOD's Arctic Report addressed the five specified reporting elements, two GAO analysts independently reviewed and compared the Arctic Report with the direction in the House Report. We considered the reporting element to be addressed when the Arctic Report explicitly addressed all parts of the element. We considered the reporting element partially addressed when the Arctic Report addressed at least one or more parts of the element, but not all parts of the element. We considered the reporting element not addressed when the Arctic Report did not explicitly address any part of the element. To assess the extent to which DOD has efforts under way to identify and prioritize the capabilities needed to meet national security objectives in the Arctic, we reviewed documentation related to DOD's Arctic operations, such as the U.S. Navy's November 2009 Arctic Roadmap, the February 2010 Quadrennial Defense Review, the U.S. European Command's April 2011 Arctic Strategic Assessment, the U.S. Coast Guard's July 2011 High Latitude Study, ${ }^{8}$ and the Navy's September 2011 Arctic Capabilities Based Assessment. We interviewed officials from the Office of the Secretary of Defense; Office of the Chairman of the Joint Chiefs of Staff; U.S. Northern Command and the North American Aerospace Defense Command; U.S. European Command; U.S. Pacific Command; U.S. Transportation Command; and U.S. Army, Navy, Air Force, and Marine Corps Arctic offices. We also interviewed Coast

7 H.R. Rep. No. 112-78, at 291 (2011).

8 ABS Consulting, High Latitude Study Mission Analysis Report, a report contracted by United States Coast Guard, July 2010. 
Guard officials to determine their contribution to and collaboration with DOD on the Arctic Report.

We conducted this performance audit from July 2011 to January 2012 in accordance with generally accepted government auditing standards. Those standards require that we plan and perform the audit to obtain sufficient, appropriate evidence to provide a reasonable basis for our findings and conclusions based on our audit objectives. We believe that the evidence obtained provides a reasonable basis for our findings and conclusions based on our audit objectives. See Appendix I for a more detailed description of our scope and methodology.

\section{Background}

\section{Diminishing Ice Opens Potential for Increased Human Activity in the Arctic}

Scientific research and projections of the changes taking place in the Arctic vary, but there is a general consensus that Arctic sea ice is diminishing. As recently as September 2011, scientists at the U.S. National Snow and Ice Data Center reported that the annual Arctic minimum sea ice extent for 2011 was the second lowest in the satellite record, and 938,000 square miles below the 1979 to 2000 average annual minimum (see appendix 3). Much of the Arctic Ocean remains ice-covered for a majority of the year, but some scientists have projected that the Arctic will be ice-diminished for periods of time in the summer by as soon as $2040 .^{9}$

These environmental changes in the Arctic are making maritime transit more feasible and are increasing the likelihood of further expansion in human activity including tourism, oil and gas extraction, commercial shipping, and fishing in the region. ${ }^{10}$ For example, in 2011, northern trans-shipping routes opened during the summer months, ${ }^{11}$ which permitted more than 40 vessels to transit between June and October 2011. The Northern Sea Route opened by mid-August, and appeared to remain open through September, while the Northwest Passage opened for periods in the summer for the fifth year in a row. See Figure 1 for locations of these shipping routes. Despite these changes, however, several enduring characteristics still provide challenges to surface navigation in the Arctic, including large amounts of winter ice and increased movement of ice from spring to fall. Increased movement of sea ice makes its location less predictable, a situation that is likely to increase the risk for ships to become trapped or

9 A Joint Coast Guard/U.S. Navy Statement on Arctic ice terminology supports usage of the term "ice-diminished" rather than "ice-free" because both agencies recognize that the region will continue to remain ice-covered during the wintertime through the end of this century and the current and projected decline in Arctic sea ice is highly variable from year to year. The term "ice-free" means that no ice of any kind is present. The term "ice-diminished" refers to sea ice concentrations of up to 15 percent ice in the area.

10 In August and December 2011, the Department of the Interior approved preliminary plans for one operator to drill for oil and gas, pending receipt of the operator's well containment plan and other requirements.

11 Open water indicates a large area of freely navigable water in which sea ice is present in concentrations less than 10 percent. No ice of land origin is present. 
damaged by ice impacts. ${ }^{12}$ DOD's Arctic Report states that scientists currently project transpolar routes will not be reliably open until around 2040 and then only for a limited period during the summer and early fall. DOD's report assessed that most national security missions will likely be limited to those months.

\section{National Policies Guide DOD and Other Stakeholders' Operations in the Arctic}

Key strategy and policy documents detail the United States' national security objectives and guide DOD's and other stakeholders' operations in the Arctic. The $2009 \mathrm{Na}-$ tional Security Presidential Directive 66/Homeland Security Presidential Directive 25, Arctic Region Policy, establishes U.S. policy with respect to the Arctic region and tasks senior officials, including the Secretaries of Defense and Homeland Security, with its implementation. This directive identifies specific U.S. national security and homeland security interests in the Arctic, including missile defense and early warning; deployment of sea and air systems for strategic sealift, maritime presence and security operations; and ensuring freedom of navigation and overflight. Additionally, the 2010 National Security Strategy identifies four enduring national interests that are relevant to the Arctic ${ }^{13}$ and states that the U.S. has broad and fundamental interests in the Arctic. The 2010 Quadrennial Defense Review also provides top-level DOD policy guidance on the Arctic, highlighting the need for DOD to work collaboratively with interagency partners such as the Coast Guard to address gaps in Arctic communications, domain awareness, search and rescue, and environmental observation and forecasting. Finally, since the Arctic region is primarily a maritime domain, existing U.S. guidance relating to maritime areas continues to apply, such as the September 2005 National Strategy for Maritime Security and National Security Presidential Directive 41/ Homeland Security Presidential Directive 13, the Maritime Security Policy.

\section{Multiple Federal Stakeholders Have Arctic Responsibilities}

DOD is responsible in the Arctic and elsewhere for securing the United States from direct attack; securing strategic access and retaining global freedom of action; strengthening existing and emerging alliances and partnerships; and establishing favorable security conditions. Additionally, the Navy has developed an Arctic Roadmap which lists Navy action items, objectives, and desired effects for the Arctic region from fiscal years 2010 to $2014 .{ }^{14}$ Focus areas include training, communications, operational investments, and environmental protection.

12 These challenges are noted in the U.S. Coast Guard's High Latitude Study, which the Coast Guard provided to Congress in July 2011.

13 The four enduring interests identified in the 2010 National Security Strategy are (1) the security of the United States, its citizens, and U.S. allies and partners; (2) a strong, innovative, and growing U.S. economy in an open international economic system that promotes opportunity and prosperity; (3) respect for universal values at home and around the world; and (4) an international order advanced by U.S. leadership that promotes peace, security, and opportunity through stronger cooperation to meet global challenges.

14 U.S. Navy, Arctic Roadmap (Washington, D.C.: 10 November 2009). 


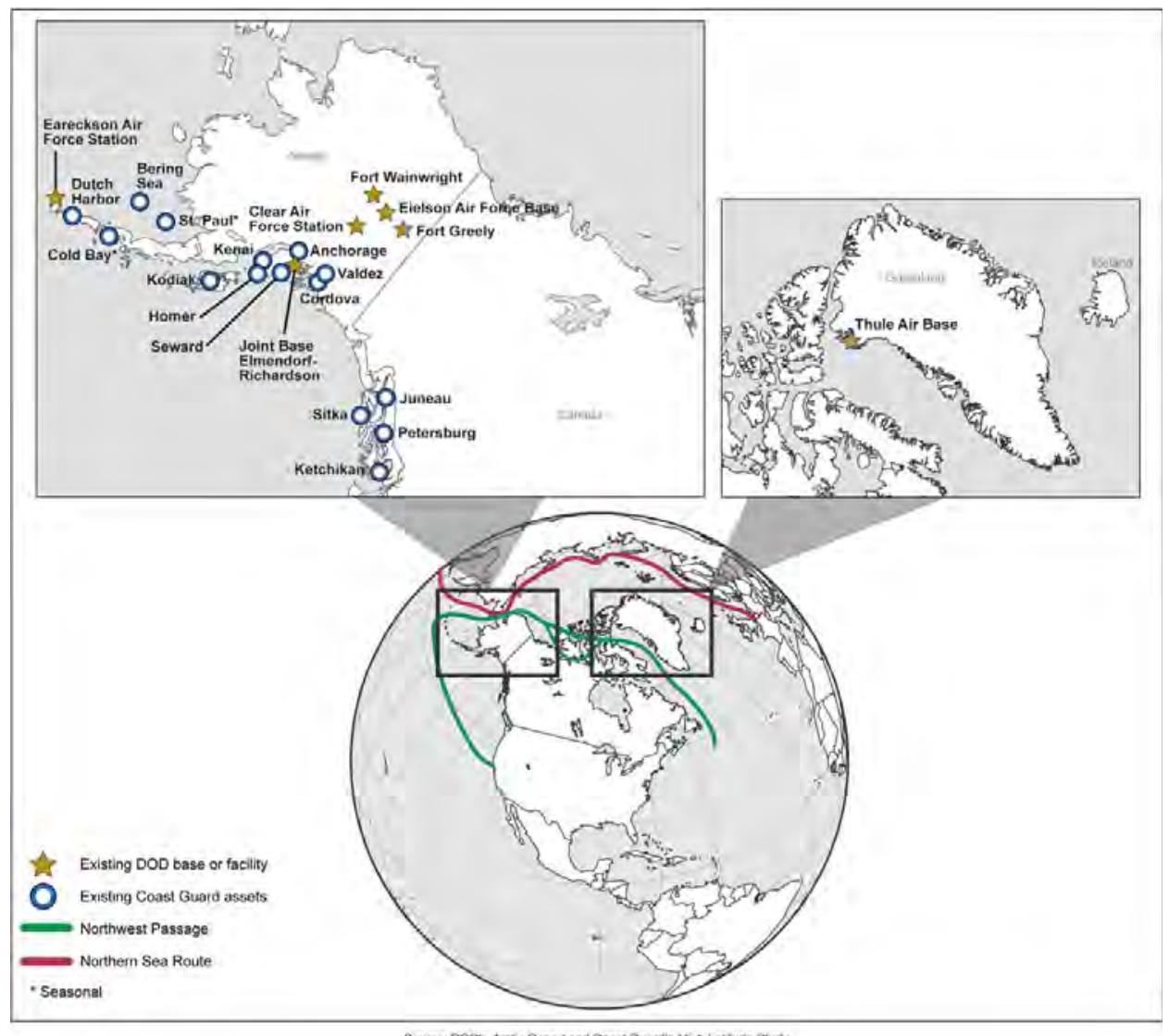

Source: DOO's Archic Report and Coast Guard's Hegh Lashice Study.

Figure 1: DOD Facilities and Coast Guard Assets in the Arctic and Alaska.

Since the Arctic is primarily a maritime domain, the Coast Guard plays a significant role in Arctic policy implementation and enforcement. The Coast Guard is a multimission, maritime military service within the Department of Homeland Security (DHS) that has responsibilities including maritime safety, security, environmental protection, and national defense, among other missions. Therefore, as more navigable ocean water emerges in the Arctic and human activity increases, the Coast Guard will face expanding responsibilities in the region. For DOD facilities and Coast Guard assets in the Arctic and Alaska, see Figure 1.

Other federal stakeholders include:

- The National Science Foundation, which is responsible for funding U.S. Arctic research-including research on the causes and impacts of climate change - and providing associated logistics and infrastructure support to conduct this research. The National Science Foundation and the Coast Guard also coordinate on the use of the Coast Guard's icebreakers for scientific research. 
- The Department of State, which is responsible for formulating and implementing U.S. policy on international issues concerning the Arctic, leading the domestic interagency Arctic Policy Group, and leading U.S. participation in the Arctic Council. ${ }^{15}$

- The Department of the Interior, which is responsible for oversight and regulation of resource development in U.S. Arctic regions. The department also coordinates with the Coast Guard on safety compliance inspections of offshore energy facilities and in the event of a major oil spill.

- The Department of Transportation and its component agency, the Maritime Administration, which works on marine transportation and shipping issues in the Arctic and elsewhere, among other things.

- The Department of Commerce's National Oceanic and Atmospheric Administration, which provides information on Arctic oceanic and atmospheric conditions and issues weather and ice forecasts, among other responsibilities.

\section{DOD's Arctic Report Addressed or Partially Addressed All Five Specified Reporting Elements}

DOD's May 2011 Arctic Report either addressed or partially addressed all of the elements specified in the House Report. ${ }^{16}$ Specifically, our analysis showed that, of the five reporting elements, DOD addressed three and partially addressed two. The elements not fully addressed were to have included a timeline to obtain needed Arctic capabilities and an assessment of the minimum and optimal number of icebreakers that may be needed to support Arctic strategic national security objectives. According to DOD officials, these elements were not fully addressed for a number of reasons such as DOD's assessment that Arctic operations are a challenge but not yet an urgency; the report's being written prior to initiating the formal DOD capabilities development process, making it difficult to provide a timeline for obtaining Arctic capabilities; and DOD's assessment that its need for icebreakers is currently limited to one mission per year. Furthermore, DOD's Arctic Report notes that significant uncertainty remains about the extent, rate, and impact of climate change in the Arctic and the pace at which human activity will increase, making it challenging for DOD to plan for possible future conditions in the region and to mobilize public or political support for investments in U.S. Arctic capabilities or infrastructure. Table 2 summarizes our assessment of the extent to which DOD's Arctic Report included each of the specified reporting elements

15 The Arctic Council is a high level intergovernmental forum for promoting cooperation, coordination and interaction among the Arctic states, with the involvement of the Arctic indigenous communities and other Arctic inhabitants on common Arctic issues, in particular issues of sustainable development and environmental protection. The eight permanent member states include Canada, Denmark (representing also Greenland and Faroe Islands), Finland, Iceland, Norway, Russia, Sweden, and the United States.

16 H.R. Rep. No. 111-491, at 337 (2010). 
Figure 2: GAO Assessment of the Extent to Which DOD's Arctic Report

Addressed the Five Specified Reporting Elements

\section{Reporting Elements and Comments}

\section{Reporting Element 1: An assessment of the strategic national security} objectives and restrictions in the Arctic region.

We determined that this element was addressed because the report includes an assessment of U.S. strategic national security objectives and restrictions in the Arctic.

\section{Reporting Element 2: An assessment of mission capabilities required} to support the strategic national security objectives and a timeline to obtain such capabilities.

We determined that this element was partially addressed because the report includes a capability gap assessment in relation to Arctic mission areas but does not provide a timeline to obtain identified capabilities. According to DOD, it was difficult to provide a timeline for developing Arctic capabilities in the report because DOD has not yet initiated the capabilities development process for the Arctic.

\section{Reporting Element 3: An assessment of an amended unified command plan that addresses opportunities of obtaining continuity of effort in the Arctic Ocean by a single combatant commander.}

We determined that this element was addressed because the report includes an assessment of the revised 2011 Unified Command Plan that addresses the impact of aligning the Arctic Ocean under a single combatant commander. DOD did not align the Arctic region under a single combatant commander; instead, it assigned both European and Northern Commands responsibility for the Arctic region in order to maintain long-standing relationships with key stakeholders. DOD assigned responsibility to Northern Command to advocate for needed Arctic capabilities.

Reporting Element 4: An assessment of the basing infrastructure required to support Arctic strategic objectives, including the need for a deep-water port in the Arctic.

We determined that this element was addressed because the report assesses the existing Arctic infrastructure (e.g., bases, ports, and airfields) to be adequate to meet near- (2010-2020) to mid-term (2020-2030) U.S. national security needs, noting that DOD does not currently anticipate a need for the construction of additional bases or a deep-draft port in Alaska between now and 2020.

\section{Reporting Element 5: An assessment of the status of and need for} icebreakers to determine whether icebreakers provide important or required mission capabilities to support Arctic strategic national security objectives, and an assessment of the minimum and optimal number of icebreakers that may be needed.

We determined that this element was partially addressed because the report discusses the status of and need for icebreakers but does not include an assessment of the minimum and optimal number of icebreakers that may be needed to support U.S. strategic national objectives in the Arctic. According to DOD officials, the Arctic Report did not address the minimum and optimal number of icebreakers that may be needed, in part, because DOD's need for ice-capable vessels is currently limited to one mission per year - the annual resupply of Thule Air Base, Greenland which has been accomplished without U.S. icebreaker support from the Coast Guard. 
and the reasons DOD officials provided for any elements that were not fully addressed. Appendix II includes our detailed evaluation of each of the specified reporting elements.

\section{DOD Has Identified Arctic Capability Gaps, but Lacks a Comprehensive Approach to Addressing Arctic Capabilities}

DOD has several efforts under way to assess the capabilities needed to support U.S. strategic objectives in the Arctic. However, it has not yet developed a comprehensive approach to addressing Arctic capabilities that would include steps such as developing a risk-based investment strategy and timeline to address near-term needs and establishing a collaborative forum with the Coast Guard to identify long-term Arctic investments.

\section{DOD Has Efforts Under Way to Assess Near-term Arctic Capability Gaps but} Lacks a Risk-Based Investment Strategy to Address These Gaps

While DOD's Arctic Report assessed a relatively low level of threat in the Arctic region, it noted three capability gaps that have the potential to hamper Arctic operations. These gaps include (1) limited communications, such as degraded high-frequency radio signals in latitudes above $70^{\circ} \mathrm{N}$ because of magnetic and solar phenomena; (2) degraded global positioning system performance that could affect missions that require precision navigation, such as search and rescue; and (3) limited awareness across all domains in the Arctic because of distances, limited presence, and the harsh environment. Other key challenges identified include: shortfalls in ice and weather reporting and forecasting; limitations in command, control, communications, computers, intelligence, surveillance, and reconnaissance because of a lack of assets and harsh environmental conditions; limited inventory of ice-capable vessels; and limited shore-based infrastructure. According to DOD's Arctic Report, capabilities will need to be reassessed as conditions change, and gaps will need to be addressed to be prepared to operate in a more accessible Arctic. Other stakeholders have also assessed Arctic capability gaps. Examples of these efforts include the following:

- U.S. Northern Command initiated a commander's estimate for the Arctic in December 2010 that, according to officials, will establish the commander's intent and missions in the Arctic and identify capability shortfalls. In addition, Northern Command identified two Arctic-specific capability gaps (communications and maritime domain awareness) in its fiscal years 2013 through 2017 integrated priority list, which defines the combatant command's highest-priority capability gaps for the near-term, including shortfalls that may adversely affect missions.

- U.S. European Command completed an Arctic Strategic Assessment in April 2011 that, among other things, identified Arctic capability gaps in the areas of environmental protection, maritime domain awareness, cooperative development of environmental awareness technology, sharing of environmental data, and lessons learned on infrastructure development. In addition, it recom- 
mended that the command conduct a more detailed mission analysis for potential Arctic missions, complete a detailed capability estimate for Arctic operations, and work in conjunction with Northern Command and the Departments of the Navy and Air Force to conduct a comprehensive capabilitiesbased assessment for the Arctic.

- DOD and DHS established the Capabilities Assessment Working Group (working group) in May 2011 to identify shared Arctic capability gaps as well as opportunities and approaches to overcome them, to include making recommendations for near-term investments. ${ }^{17}$ The working group was directed by its Terms of Reference to focus on four primary capability areas when identifying potential collaborative efforts to enhance Arctic capabilities, including near-term investments. Those capability areas include maritime domain awareness, communications, infrastructure, and presence. The working group was also directed to identify overlaps and redundancies in established and emerging DOD and DHS Arctic requirements. As the advocate for Arctic capabilities, Northern Command was assigned lead responsibility for DOD in the working group, while the Coast Guard was assigned lead responsibility for DHS. The establishment of the working group — which, among other things, is to identify opportunities for bi-departmental action to close Arctic capability gaps and issue recommendations for near-term investments - helps to ensure that collaboration between the Coast Guard and DOD is taking place to identify near-term capabilities needed to support current planning and operations. Although the working group is developing a paper with its recommendations, officials indicated that additional assessments would be required to address those recommendations.

- U.S. Navy completed its first Arctic capabilities-based assessment in September 2011 and is developing a second capabilities-based assessment focused on observing, mapping, and environmental prediction capabilities in the Arctic, which officials expect to be completed in the spring of 2012. The Navy's first Arctic capabilities-based assessment identified three critical capability gaps as the highest priorities, including the capabilities to provide environmental information; maneuver safely on the sea surface; and conduct training, exercise, and education. This assessment recommended several near-term actions to address these gaps.

17 The Capabilities Assessment Working Group was chartered by the DOD and DHS Capabilities Development Working Group, established by the DOD Under Secretary for Acquisition, Technology, and Logistics; the DHS Under Secretary for Science and Technology; and the DHS Under Secretary for Management. The Capabilities Development Working Group is a mechanism for improving cooperation and facilitating decision-making on DOD-DHS capability development. The group's charter states it will meet quarterly to discuss topics of mutual interest. 
DOD's Arctic Report states that the development of Arctic capabilities requires a deliberate risk-based investment strategy, but DOD has not developed such a strategy. Although DOD and its components have identified current Arctic capability gaps, the department may not be taking appropriate steps to best ensure its future preparedness because DOD lacks a risk-based investment strategy and a timeline for addressing near-term capability needs. According to DOD officials, there had been no Arctic-related submissions to its formal capabilities development process as of September 2011; this process could take two or more years to be approved, followed by additional time for actual capability development. ${ }^{18}$

Our prior work has shown that industry best practices include using a risk-based strategy to prioritize and address capability gaps. ${ }^{19}$ A risk-based investment strategy may be used to define and prioritize related resource and operational requirements, as well as develop a timeline to obtain those requirements. This strategy includes five key phases: (1) setting strategic goals and objectives, and determining constraints; (2) assessing risks; (3) evaluating alternatives for addressing these risks; (4) selecting the appropriate alternatives; and (5) implementing the alternatives and monitoring the progress made and results achieved. Even though DOD has made preliminary efforts to identify Arctic capability gaps and assess strategic objectives, constraints, and risks in the Arctic, DOD has not yet evaluated, selected, or implemented alternatives for prioritizing and addressing near-term Arctic capability needs. For example, DOD officials stated that they are at the beginning stages of assessing Arctic capability gaps and challenges and have not yet begun to consider potential alternative solutions for addressing these gaps. Alternatives could include those that would minimize DOD investments by leveraging capabilities of interagency and international partners or they could also include submissions to DOD's formal capabilities development process. Another alternative could include accepting the risk of potentially being late to develop these needed capabilities in order to provide limited fiscal resources to other priorities.

Given that the opening in the Arctic presents a wide range of challenges for DOD, a risk-based investment strategy and timeline can help DOD develop the capabilities needed to meet national security interests in the region. Without a risk-based investment strategy and timeline for prioritizing and addressing near-term Arctic capability gaps and challenges, which is periodically updated to reflect evolving needs, DOD could be slow to develop needed capabilities, potentially facing operational risk and higher costs if the need arises to execute plans rapidly. Conversely, DOD could move too early, making premature Arctic investments that take resources from other, more pressing needs or producing capabilities that could be outdated before they are used.

18 For further discussion on DOD's formal capabilities development process (the Joint Capabilities Integration and Development System) see GAO, Defense Acquisitions: DOD's Requirements Determination Process Has Not Been Effective in Prioritizing Joint Capabilities, GAO-08-1060 (Washington, D.C.: 25 September 2008).

19 GAO, Intelligence, Surveillance, and Reconnaissance: DOD Needs a Strategic, Risk-Based Approach to Enhance Its Maritime Domain Awareness, GAO-11-621 (Washington, D.C.: 20 June 2011). 


\section{DOD and DHS Have Established a Collaborative Forum to Identify Potential Near-term Investments but Not Long-term Needs}

While DOD and DHS have established the working group to identify shared near-term Arctic capability gaps, this collaborative forum is not intended to address long-term Arctic capability gaps or identify opportunities for joint investments over the longerterm. DOD acknowledged the importance of collaboration with the Coast Guard over the long-term in its 2010 Quadrennial Defense Review, which states that the department must work with the Coast Guard and DHS to develop Arctic capabilities to support both current and future planning and operations. According to DOD and Coast Guard officials, although the working group is primarily focused on near-term investments, it has discussed some mid- to long-term capability needs. However, DOD and Coast Guard officials stated that after the completion of the working group's paper, expected in January 2012, the working group will have completed the tasks detailed in the Terms of Reference and will be dissolved. Consequently, no forum will exist to further address any mid- to long-term capability needs.

Although we have previously reported that there are several existing interagency organizations working on Arctic issues, these organizations do not specifically address Arctic capability needs. These organizations include the Interagency Policy Committee on the Arctic, the Arctic Policy Group, and the Interagency Arctic Research Policy Committee, among others. ${ }^{20}$ DOD and DHS also have long-standing memorandums of agreement related to coordination between DOD and the Coast Guard in both maritime homeland security and maritime homeland defense. The objectives of these interagency organizations range from developing coordinated research policy for the Arctic region to tracking implementation of national Arctic policy to identifying implementation gaps, but do not specifically address capability gaps in the Arctic. According to DOD and Coast Guard officials we spoke with, only the working group is focused specifically on addressing Arctic capabilities. After the working group completes its tasks in January 2012, there will be no DOD and Coast Guard organization focused specifically on reducing overlap and redundancies or collaborating to address Arctic capability gaps in support of future planning and operations, as is directed by the 2010 Quadrennial Defense Review.

While Northern Command officials stated they have plans for periodic reassessment of long-term capability needs, such as icebreakers or basing infrastructure in-

20 The Interagency Policy Committee on the Arctic was created in March 2010 to coordinate governmentwide implementation of National Security Presidential Directive 66/Homeland Security Presidential Directive 25, and is co-chaired by the White House's National Security Staff and Council on Environmental Quality. The Arctic Policy Group was established in 1971 to coordinate U.S. policy positions on international Arctic issues and is led by the Department of State. The Interagency Arctic Research Policy Committee was established by the Arctic Research and Policy Act of 1984 to help set priorities for future Arctic research. In July 2010, responsibility for this committee shifted to the National Science and Technology Council. See GAO-10-870, appendix IV for descriptions of other select interagency coordination efforts. 
cluding a deep-water port, it is not clear how those plans consider collaboration with the Coast Guard. For example, officials stated the biennial review of Northern Command's Theater Campaign Plan ${ }^{21}$ and Strategic Infrastructure Master Plan ${ }^{22}$ will consider long-term capability and infrastructure needs. They added that the commander's Arctic Estimate is reviewed annually and also considers long-term priorities, such as identifying a need for icebreakers. However, the officials stated that the Arctic Estimate does not identify how DOD would acquire those icebreakers or how it would coordinate with the Coast Guard - the operator of the nation's icebreakers ${ }^{23}$ - to reconstruct existing or build new icebreakers. The Coast Guard has a more immediate need to develop Arctic capabilities such as icebreakers and has taken steps to address some long-term capability gaps. Meanwhile, given that it could take approximately 10 years to develop icebreakers, the process for DOD and the Coast Guard to identify and procure new icebreakers would have to begin within the next year to ensure that U.S. heavy icebreaking capabilities are maintained beyond 2020 .

Our prior work has shown that collaboration with partners can help avoid wasting scarce resources and increase effectiveness of efforts. ${ }^{24}$ Without specific plans for a collaborative forum between DOD and the Coast Guard to address long-term Arctic capability gaps and to identify opportunities for joint investments over the longer-term, DOD may miss opportunities to leverage resources with the Coast Guard to enhance future Arctic capabilities.

21 A theater campaign plan encompasses the activities of a supported geographic combatant commander, which accomplish strategic or operational objectives within a theater of war or theater of operations, and translates national or theater strategy into operational concepts and those concepts into unified action.

22 A strategic infrastructure master plan identifies infrastructure requirements, installation and facility locations, existing or planned capabilities at each location, and required infrastructure improvements.

23 The Navy and the Coast Guard have a long-standing memorandum of agreement regarding the use of the nation's icebreakers - the Coast Guard operates the nation's icebreakers and uses them, when needed, to support the Navy. The 1965 U.S. Navy-U.S. Treasury Memorandum of Agreement was executed to permit consolidation of the icebreaker fleet under one agency. That rationale was reinforced by a 1982 Roles and Missions Study which stated that polar icebreakers should be centrally managed by one agency and that the Coast Guard was the appropriate one because of the multimission nature of polar ice operations. This memorandum of agreement was updated in 2008. The signatories were DOD and DHS and the agreement included an update on responsibilities for coastal security.

24 GAO, Interagency Collaboration: Key Issues for Congressional Oversight of National Security Strategies, Organizations, Workforce, and Information Sharing, GAO-09-904SP (Washington, D.C.: 25 September 2009); and GAO, National Security: Key Challenges and Solutions to Strengthen Interagency Collaboration, GAO-10-822T (Washington, D.C.: 9 June 2010). 


\section{Conclusions}

At this time, significant DOD investments in Arctic capabilities may not be needed, but that does not preclude taking steps to anticipate and prepare for Arctic operations in the future. Addressing near-term gaps is essential for DOD to have the key enabling capabilities it needs to communicate, navigate, and maintain awareness of activity in the region. An investment strategy that identifies and prioritizes near-term Arctic capability needs and identifies a timeline to address them would be useful for decision makers in planning and budgeting. Without taking deliberate steps to analyze risks in the Arctic and prioritize related resource and operational requirements, DOD could later find itself faced with urgent needs, resulting in higher costs that could have been avoided.

In addition, unless DOD and DHS continue to collaborate to identify opportunities for interagency action to close Arctic capability gaps, DOD could miss out on opportunities to work with the Coast Guard to leverage resources for shared needs. DOD may choose to create a new collaborative forum or incorporate this collaboration into an existing forum or process. Given the different missions and associated timelines of DOD and the Coast Guard for developing Arctic capabilities, it is important that the two agencies work together to avoid fragmented efforts and reduce unaffordable overlap and redundancies while addressing Arctic capability gaps in support of future planning and operations.

\section{Recommendations for Executive Action}

To more effectively leverage federal investments in Arctic capabilities in a resourceconstrained environment and ensure needed capabilities are developed in a timely way, we recommend that the Secretary of Defense, in consultation with the Secretary of the Department of Homeland Security, take the following two actions:

- develop a risk-based investment strategy that: 1) identifies and prioritizes near-term Arctic capability needs, 2) develops a timeline for addressing them, and 3 ) is updated as appropriate; and

- $\quad$ establish a collaborative forum with the Coast Guard to fully leverage federal investments and help avoid overlap and redundancies in addressing long-term Arctic capability needs.

\section{Agency Comments and Our Evaluation}

In written comments on a draft of this report, DHS concurred with both of our recommendations. For its part, DOD partially concurred with both of our recommendations. It generally agreed that the department needed to take action to address the issues we raised but indicated it is already taking initial steps to address them. Technical comments were provided separately and incorporated as appropriate.

With respect to DOD's comments on our first recommendation, DOD stated that its existing processes-including prioritizing Arctic capability needs through the Com- 
mander's annual integrated priority lists; balancing those needs against other requirements through the annual planning, programming, budgeting, and execution system process; and addressing Service requirements through program objective memorandum submissions - enable DOD to balance the risk of being late-to-need with the opportunity cost of making premature Arctic investments. However, DOD's response did not address how it would develop a risk-based investment strategy. As stated in our report, DOD has considered some elements of such a risk-based investment strategy by setting strategic goals and objectives, determining constraints, and assessing risks (such as Northern Command's inclusion of two Arctic-specific capability needs in its fiscal years 2013 through 2017 integrated priority list). However, DOD has not yet conducted the remaining three phases of a risk-based investment strategy: evaluating alternatives for addressing these risks, selecting the appropriate alternatives, and implementing the alternatives and monitoring the progress made and results achieved. We believe that considering potential alternative solutions, such as leveraging the capabilities of interagency or international partners, could help minimize DOD's investment in Arctic capabilities. DOD's Arctic Report also emphasized the need for a risk-based investment strategy, noting that "the long lead time associated with capability development, particularly the procurement of space-based assets and ships, requires a deliberate risk-based investment strategy" and noted that "additional capability analysis will be required." By developing a risk-based investment strategy to prioritize near-term investment needs and a timeline for addressing them, DOD can be better prepared in its planning and budgeting decisions.

With respect to our second recommendation, both DOD and DHS cited the importance of collaboration to develop Arctic capabilities and identified some existing forums that include Arctic issues, such as the annual Navy and Coast Guard staff talks and the joint DOD-DHS Capabilities Development Working Group. Our report also identified additional existing interagency organizations working on Arctic issues, and we agree that these forums can help avoid overlap and redundancies in addressing long-term Arctic capability needs. However, these forums do not specifically focus on Arctic capability needs, and no DOD and Coast Guard forum will be focused on reducing overlap and redundancies or collaborating to address Arctic capability gaps following the dissolution of the Arctic Capabilities Assessment Working Group in January 2012. We continue to believe that focusing specifically on long-term Arctic capability needs will enable DOD and the Coast Guard to better leverage resources for shared needs. 


\section{List of Committees}

The Honorable Carl Levin, Chairman

The Honorable John McCain, Ranking Member

Committee on Armed Services, United States Senate

The Honorable Daniel Inouye, Chairman

The Honorable Thad Cochran, Ranking Member

Subcommittee on Defense Committee on Appropriations, United States Senate

The Honorable Howard P. McKeon, Chairman

The Honorable Adam Smith, Ranking Member

Committee on Armed Services, House of Representatives

The Honorable C.W. "Bill" Young, Chairman

The Honorable Norman D. Dicks, Ranking Member

Subcommittee on Defense, Committee on Appropriations, House of Representatives 


\section{Appendix I: Objectives, Scope, and Methodology}

The objectives of our work were to determine the extent to which (1) the Department of Defense (DOD) report on the Arctic addresses the reporting elements specified in House Report $111-491^{25}$ and (2) DOD has efforts under way to identify and prioritize the capabilities needed to meet national security objectives in the Arctic. To gather information for both objectives we reviewed various DOD and Coast Guard documentation. We interviewed officials from the Office of the Secretary of Defense; Office of the Chairman of the Joint Chiefs of Staff; U.S. Northern Command and the North American Aerospace Defense Command; U.S. European Command; U.S. Pacific Command; U.S. Transportation Command; and U.S. Army, Navy, Air Force, and Marine Corps Arctic offices. We also interviewed Coast Guard officials to determine their contribution to DOD's efforts to identify and prioritize capabilities.

To address the extent to which DOD's report on the Arctic addresses the reporting elements specified in House Report 111-491, we evaluated the DOD Report to Congress on Arctic Operations and the Northwest Passage (Arctic Report) issued in May 2011. We determined that the extent to which DOD addressed each specified element would be rated as either "addressed," "partially addressed," or "not addressed." These categories were defined as follows:

- Addressed: An element is addressed when the Arctic Report explicitly addresses all parts of the element.

- Partially addressed: An element is partially addressed when the Arctic Report addresses at least one or more parts of the element, but not all parts of the element.

- Not addressed: An element is not addressed when the Arctic Report did not explicitly address any part of the element.

Specifically, two GAO analysts independently reviewed and compared the Arctic Report with the direction in the House Report; assessed whether each element was addressed, partially addressed, or not addressed; and recorded their assessment and the basis for the assessment. The final assessment reflected the analysts' consensus based on the individual assessments. In addition, we interviewed DOD officials involved in preparing the Arctic Report to discuss their interpretation of the direction in the House Report and the DOD report's findings. To provide context, our assessment also reflected our review of relevant DOD and Coast Guard documents, as well as issues raised in recent GAO reports that specifically relate to some of the specified reporting elements.

To address the extent to which DOD has efforts under way to identify and prioritize the capabilities needed to meet national security objectives in the Arctic, we reviewed documentation related to DOD's Arctic operations, such as the U.S. Navy's November

25 H.R. Rep. No. 111-491, at 337 (2010). This report accompanied H.R. 5136, a proposed bill for the National Defense Authorization Act for Fiscal Year 2011. 
2009 Arctic Roadmap, the February 2010 Quadrennial Defense Review, the U.S. European Command's April 2011 Arctic Strategic Assessment, the U.S. Coast Guard's July 2011 High Latitude Study, and the Navy's September 2011 Arctic Capabilities Based Assessment. We also interviewed officials from various DOD and Coast Guard offices.

We conducted this performance audit from July 2011 to January 2012 in accordance with generally accepted government auditing standards. Those standards require that we plan and perform the audit to obtain sufficient, appropriate evidence to provide a reasonable basis for our findings and conclusions based on our audit objectives. We believe that the evidence obtained provides a reasonable basis for our findings and conclusions based on our audit objectives. 


\section{Appendix II: Extent to which DOD's Arctic Report Addressed Specified Reporting Elements}

\section{Reporting Element 1: Strategic National Security Objectives and Restric- tions in the Arctic}

\section{Detailed Assessment of This Element}

We determined that the Department of Defense (DOD) addressed this element because the Report to Congress on Arctic Operations and the Northwest Passage (Arctic Report) includes an assessment of U.S. strategic national security objectives and restrictions in the Arctic. Specifically, the report states that DOD reviewed national-level policy guidance and concluded that the overarching strategic national security objective for the Arctic is a stable and secure region where U.S. national interests are safeguarded and the U.S. homeland is protected (see Figure 3 for descriptions of the policy guidance documents DOD reviewed). The report further identifies two DOD strategic objectives to achieve the desired end-state for the Arctic: (1) prevent and deter conflict and (2) prepare to respond to a wide range of challenges and contingencies. In addition, the report identifies and examines restrictions in the Arctic. For example, the report states that uncertainty about the extent, impact, and rate of climate change in the Arctic will make it challenging to plan for possible future conditions in the region and to mobilize public or political support for investments in U.S. Arctic capabilities or infrastructure.

\section{Related Findings from Previous GAO Reports}

In 2010, we reported on the difficulties associated with developing capabilities needed to understand the extent, rate, and impact of climate change. Specifically, we found that while agencies have taken steps to plan for some continued climate observations via satellite data in the near-term, they lack a strategy for the long-term provision of such data. ${ }^{26}$ For example, we reported that DOD has not established plans to restore the full set of capabilities intended for the National Polar-orbiting Operational Environmental Satellite System over the life of the program. We noted that without a comprehensive long-term strategy for continuing environmental measurements over the coming decades and a means for implementing it, agencies will continue to independently pursue their immediate priorities on an ad-hoc basis, the economic benefits of a coordinated approach to investments in earth observation may be lost, and our nation's ability to understand climate change may be limited.

${ }^{26}$ GAO, Environmental Satellites: Strategy Needed to Sustain Critical Climate and Space Weather Measurements, GAO-10-456 (Washington, D.C.: 27 April 2010). 


\begin{tabular}{|c|c|c|c|}
\hline $\begin{array}{c}\text { National Security } \\
\text { Presidential } \\
\text { Directive } 66 / \text { Homeland } \\
\text { Security Presidential } \\
\text { Directive } 25 \text {, Arctic } \\
\text { Region Policy }\end{array}$ & $\begin{array}{c}2010 \text { National } \\
\text { Security Strategy }\end{array}$ & $\begin{array}{l}\text { Executive Order } \\
13547 \text { Stewardship of } \\
\text { the Ocean, Our Coasts, } \\
\text { and the Great Lakes }\end{array}$ & $\begin{array}{l}2010 \text { Quadrennial } \\
\text { Defense Review }\end{array}$ \\
\hline $\begin{array}{l}\text { Identifies U.S. national } \\
\text { security and homeland } \\
\text { security interests in the } \\
\text { Arctic. National security } \\
\text { interests include such } \\
\text { matters as missile } \\
\text { defense and early } \\
\text { warning; deployment of } \\
\text { sea and air systems for } \\
\text { strategic sealift, strategic } \\
\text { deterrence, maritime } \\
\text { presence, and maritime } \\
\text { security operations; and } \\
\text { ensuring freedom of } \\
\text { navigation and overflight. } \\
\text { In addition, the United } \\
\text { States has fundamental } \\
\text { homeland security } \\
\text { interests in preventing } \\
\text { terrorist attacks and } \\
\text { mitigating those criminal } \\
\text { or hostile acts that could } \\
\text { increase the United } \\
\text { States' vulnerability to } \\
\text { terrorism in the Arctic } \\
\text { region. }\end{array}$ & $\begin{array}{l}\text { Identifies six U.S. } \\
\text { interests in the Arctic: } \\
\text { - to meet national } \\
\text { security needs; } \\
\text { - protect the } \\
\text { environment; } \\
\text { - responsibly manage } \\
\text { resources; } \\
\text { - account for indigenous } \\
\text { communities; } \\
\text { - support scientific } \\
\text { research; and } \\
\text { - strengthen international } \\
\text { cooperation on a wide } \\
\text { range of issues. }\end{array}$ & $\begin{array}{l}\text { States that: "The ocean, } \\
\text { our coasts, and the } \\
\text { Great Lakes provide } \\
\text { jobs, food, energy } \\
\text { resources, ecological } \\
\text { services, recreation, and } \\
\text { tourism opportunities, } \\
\text { and play critical roles in } \\
\text { our Nation's transporta- } \\
\text { tion, economy, and } \\
\text { trade, as well as the } \\
\text { global mobility of our } \\
\text { Armed Forces and the } \\
\text { maintenance of } \\
\text { international peace and } \\
\text { security." }\end{array}$ & $\begin{array}{l}\text { Establishes four priority } \\
\text { objectives for DOD: } \\
\text { prevail in today's wars; } \\
\text { prevent and deter } \\
\text { conflict; prepare to } \\
\text { defeat adversaries and } \\
\text { succeed in a wide range } \\
\text { of contingencies; and } \\
\text { preserve and enhance } \\
\text { the all-volunteer force. } \\
\text { With regards to the } \\
\text { Arctic, it states that DOD } \\
\text { must work with the } \\
\text { Coast Guard and the } \\
\text { Department of } \\
\text { Homeland Security to } \\
\text { address gaps in Arctic } \\
\text { communications, domain } \\
\text { awareness, search and } \\
\text { rescue, and environmen- } \\
\text { tal observation and } \\
\text { forecasting capabilities } \\
\text { to support both current } \\
\text { and future planning and } \\
\text { operations. }\end{array}$ \\
\hline & $\begin{array}{l}\text { Arctic national s } \\
\text { "A stable and secure re } \\
\text { ts are safeguarded and }\end{array}$ & $\begin{array}{l}\text { curity objective: } \\
\text { ion where U.S. national } \\
\text { e U.S. homeland is prote }\end{array}$ & \\
\hline
\end{tabular}

Source: GAO analysis.

Figure 3: Policy Guidance on the Arctic Identified in DOD’s Arctic Report.

\section{Reporting Element 2: Required Mission Capabilities and a Timeline to Ob- tain Such Capabilities}

\section{Detailed Assessment of This Element}

We determined that DOD partially addressed this element because the Arctic Report includes a capability gap assessment in relation to Arctic mission areas but does not provide a timeline to obtain such capabilities. Specifically, the report identifies potential Arctic capability gaps over the near- (2010-2020), mid- (2020-2030), and far-term (beyond 2030) that may affect DOD's ability to accomplish four of nine mission areas in the region, including maritime domain awareness, maritime security, search and rescue, and sea control. The report notes that three capability gaps in particular have the 
potential to hamper Arctic operations across all time frames: (1) insufficient communications architecture, (2) degraded Global Positioning System performance, and (3) extremely limited domain awareness. Other key challenges identified include: shortfalls in ice and weather reporting and forecasting; limitations in command, control, communications, computers, intelligence, surveillance and reconnaissance; and limited shore-based infrastructure and inventory of ice-capable vessels. Although DOD states in the report that capabilities will need to be reassessed as conditions change and gaps addressed in order to be prepared to operate in a more accessible Arctic, it does not provide a timeline for addressing capability gaps or challenges identified.

Related Findings from Previous GAO Reports

We previously reported on the challenges DOD and Coast Guard face in achieving maritime domain awareness, a capability gap identified in DOD's Arctic Report. For example, in 2011 we found that DOD lacks a strategic, risk-based approach to manage its maritime domain awareness efforts and to address high priority capability gaps. ${ }^{27}$ To improve DOD's ability to manage the implementation of maritime domain awareness across DOD, we recommended that DOD develop and implement a departmentwide strategy that: identifies objectives and roles and responsibilities for achieving maritime domain awareness; aligns efforts and objectives with DOD's process for determining requirements and allocating resources; identifies capability resourcing responsibilities; and includes performance measures. We also recommended that DOD, in collaboration with other stakeholders such as the Coast Guard, perform a comprehensive risk-based analysis to prioritize and address DOD's critical maritime capability gaps and guide future investments. DOD concurred with our recommendations and identified actions it is taking —or plans to take - to address them. We also reported in 2010 that the Coast Guard faces challenges in achieving Arctic domain awareness, including inadequate Arctic Ocean and weather data, lack of communication infrastructure, limited intelligence information, and lack of a physical presence in the Arctic. ${ }^{28}$ Other challenges reported include minimal assets and infrastructure for Arctic missions and diminishing fleet expertise for operating in Arctic-type conditions.

\section{Reporting Element 3: Amended Unified Command Plan}

\section{Detailed Assessment of This Element}

We determined that DOD addressed this element because the Arctic Report includes an assessment of the revised April 2011 Unified Command Plan that addresses the impact of aligning the Arctic Ocean under a single combatant commander. The April 2011 Unified Command Plan shifted areas of responsibility boundaries in the Arctic region.

27 GAO, Intelligence, Surveillance, and Reconnaissance: DOD Needs a Strategic, Risk-Based Approach to Enhance Its Maritime Domain Awareness, GAO-11-621 (Washington, D.C.: 20 June 2011).

28 GAO, Coast Guard: Efforts to Identify Arctic Requirements Are Ongoing, but More Communication about Agency Planning Efforts Would Be Beneficial, GAO-10-870 (Washington, D.C.: 15 September 2010). 


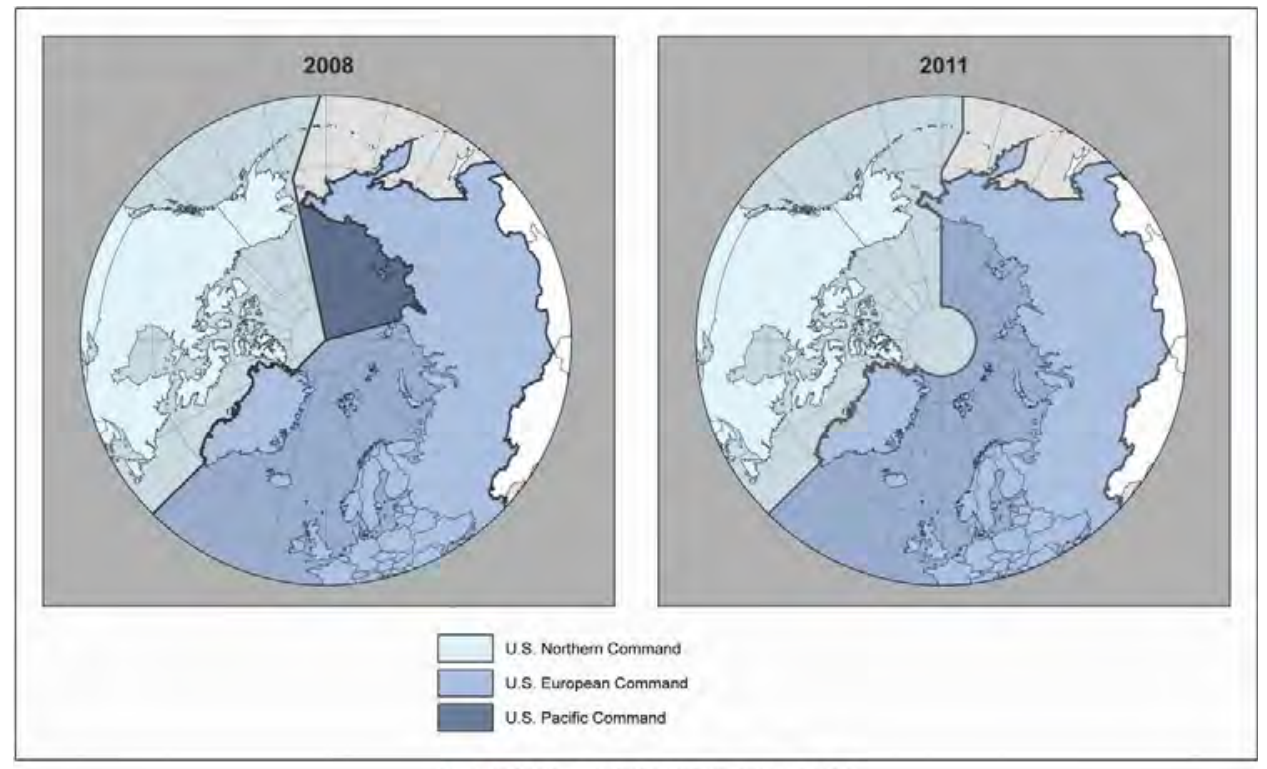

Source: GAO analysis of the 2008 and 2011 Unified Command Plans.

Figure 4: Arctic Responsibilities under the Unified Command Plan: 2008 and 2011.

As a result of this realignment, responsibility for the Arctic region is now shared between U.S. Northern and U.S. European Commands - previously, under the 2008 Unified Command Plan, the two commands and U.S. Pacific Command shared responsibility for the region, as shown in figure 4. In addition, the April 2011 Unified Command Plan assigned Northern Command responsibility for advocating for Arctic capabilities. The Arctic Report states that having two combatant commands responsible for a portion of the Arctic Ocean aligned with adjacent land boundaries is an arrangement best suited to achieve continuity of effort with key regional partners and that aligning the entire Arctic Ocean under a single combatant command would disrupt progress in theater security cooperation achieved over decades of dialogue and confidence building by Northern and European Commands with regional stakeholders. The report also notes that although having multiple combatant commands with responsibility in the Arctic Ocean makes coordination more challenging, having too few would leave out key stakeholders, diminish long-standing relationships, and potentially alienate important partners.

\section{Reporting Element 4: Required Basing Infrastructure, Including the Need for a Deep-Water Port}

\section{Detailed Assessment of This Element}

We determined that DOD addressed this element because the Arctic Report assesses the existing Arctic infrastructure to be adequate to meet near- (2010-2020) to mid-term (2020-2030) U.S. national security needs, noting that DOD does not currently antici- 
pate a need for the construction of additional bases or a deep-draft port in Alaska before 2020. Specifically, the Arctic Report examines the defense infrastructure such as bases, ports, and airfields needed to support DOD strategic objectives for the Arctic, and it discusses the environmental challenges and higher costs associated with construction and maintenance of Arctic infrastructure. It concludes that with the low potential for armed conflict in the region, existing DOD posture is adequate to meet U.S. defense needs through 2030. In addition, the report states that DOD does not currently anticipate a need for the construction of a deep-draft port in Alaska before 2020. The report does not address the basing infrastructure required to support long-term U.S. national security needs. The report notes that given the long lead times for construction of major infrastructure in the region, DOD will periodically reevaluate this assessment as activity in the region gradually increases and the combatant commanders update their regional plans on a regular basis. The report also states that one area for future assessment might be the need for a co-located airport and port facility suitable for deployment of undersea search and rescue assets but does not provide a timeline for completing such an assessment.

\section{Related Findings from Previous GAO Reports}

Our prior work has identified the high costs associated with operating and maintaining installations outside the contiguous United States. In February 2011, we reported that DOD's posture-planning guidance does not require the combatant commands to compile and report comprehensive cost data associated with posture requirements or to analyze the costs and benefits of posture alternatives when considering changes to posture. ${ }^{29}$ We noted that without such requirements, DOD's posture-planning process will continue to lack critical information that could be used by decision makers as they deliberate posture requirements and potential opportunities to obtain greater cost efficiencies may not be identified. We recommended that DOD revise its posture-planning guidance to require combatant commands to include the costs associated with initiatives that would alter future posture, and that DOD provide guidance on how the combatant commands should analyze the costs and benefits of alternative courses of action when considering proposed changes to posture. DOD agreed with our recommendations and identified corrective actions, but additional steps are needed to fully address the recommendations. These findings underscore the importance of DOD and Northern Command identifying and analyzing the costs and benefits of alternative courses of action associated with future defense posture in the Arctic.

\section{Reporting Element 5: Status of and Need for Icebreakers, Including an Assessment of the Minimum and Optimal Number of Icebreakers}

Detailed Assessment of This Element

We determined that DOD partially addressed this element because the Arctic Report identifies current U.S. polar icebreakers, but it provides limited details on the status of

29 GAO, Defense Management: Additional Cost Information and Stakeholder Input Needed to Assess Military Posture in Europe, GAO-11-131 (Washington, D.C.: 3 February 2011). 
U.S. icebreakers and does not assess the minimum and optimal number of icebreakers that may be needed. For example, the Arctic Report states that the U.S. Coast Guard owns the U.S. inventory of three icebreakers, while the U.S. Navy owns one icestrengthened tanker. The three U.S. icebreakers include the Healy, a medium-duty icebreaker with an estimated 18 years of service life remaining; the Polar Sea, a heavyduty icebreaker expected to be decommissioned in fiscal year 2011 because of engine problems; and the Polar Star, a heavy-duty icebreaker expected to return to service in 2013 with an estimated 7 to 10 years of service life remaining. The Arctic Report also states that DOD's current needs are met by foreign-flagged commercial contract vessels or through cooperation with Canada. It notes that in the future, assured access in the Arctic could be met by means other than icebreakers, including submarines, aircraft, and ice-strengthened vessels. However, the Arctic Report does not provide an assessment of the minimum or optimal number of icebreakers or other needed assets, although it does note that the U.S. Navy's 2011 Capabilities Based Assessment and a Department of Homeland Security (DHS) effort to study icebreaking options in fiscal year 2012 will provide further information about future U.S. icebreaking needs.

\section{Related Findings from Other Coast Guard and DHS Reports}

In July 2011, the Coast Guard provided the High Latitude Study to Congress, which concluded that the Coast Guard requires six heavy and four medium icebreakers to fulfill its statutory mission requirements and the Navy's presence requirements in the polar regions. The report also identified six scenarios for meeting needs in the Arctic that include capabilities beyond icebreakers, such as non-icebreaker cutters and aircraft. The DHS Office of the Inspector General also reported in January 2011 that the Coast Guard is unable to meet its current Arctic mission requirements with existing icebreaking resources, including providing DOD with assured access to the region, and without funding for new icebreakers or service life extensions for existing icebreakers with sufficient lead time, the U.S. will lose all polar icebreaking capabilities by 2029. However, as we have previously reported, given the uncertainty about the Coast Guard's long-term budget outlook, it may be a significant challenge for the Coast Guard to obtain these Arctic capabilities. ${ }^{30}$ In November 2011, the Coast Guard provided to Congress a report that assessed options for recapitalizing its existing icebreaker fleet. The report found that the most cost effective option is to build two new heavy icebreakers, while performing minimal maintenance to keep the existing icebreakers operational while construction is taking place. However, the report noted that acquiring two new heavy icebreakers through the Coast Guard budget would have significant adverse impact on all Coast Guard activities, and concluded that the recapitalization of the polar icebreaker fleet cannot be funded within the Coast Guard budget.

30 GAO-10-870. 
THE QUARTERLY JOURNAL

Appendix III: Change in Summer Minimum Ice Extent from 2001 to 2011, Compared with the 1979 to 2000 Median Minimum Ice Extent

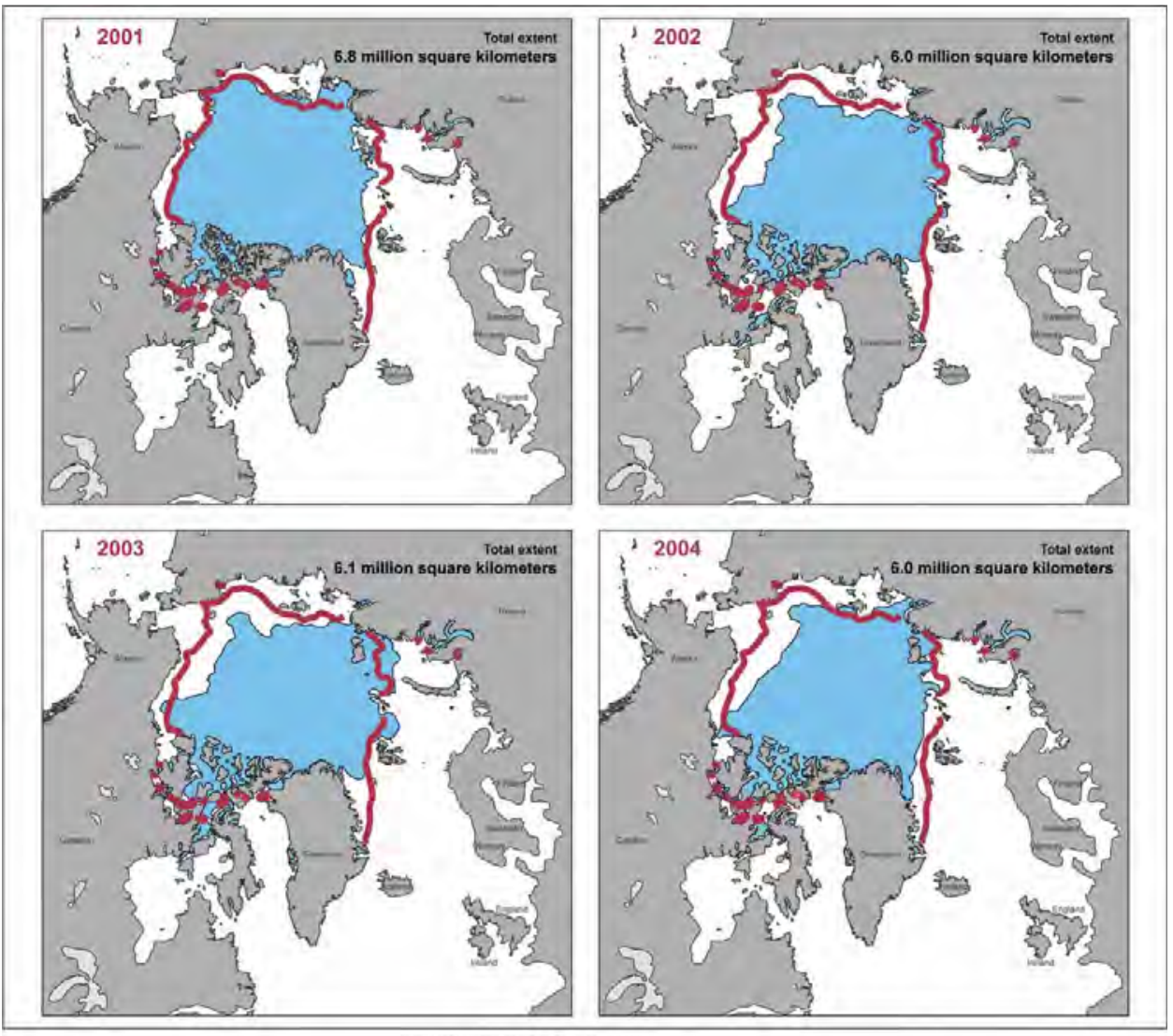

Source. National Snow and lce Data Cermec. 
WINTER 2011

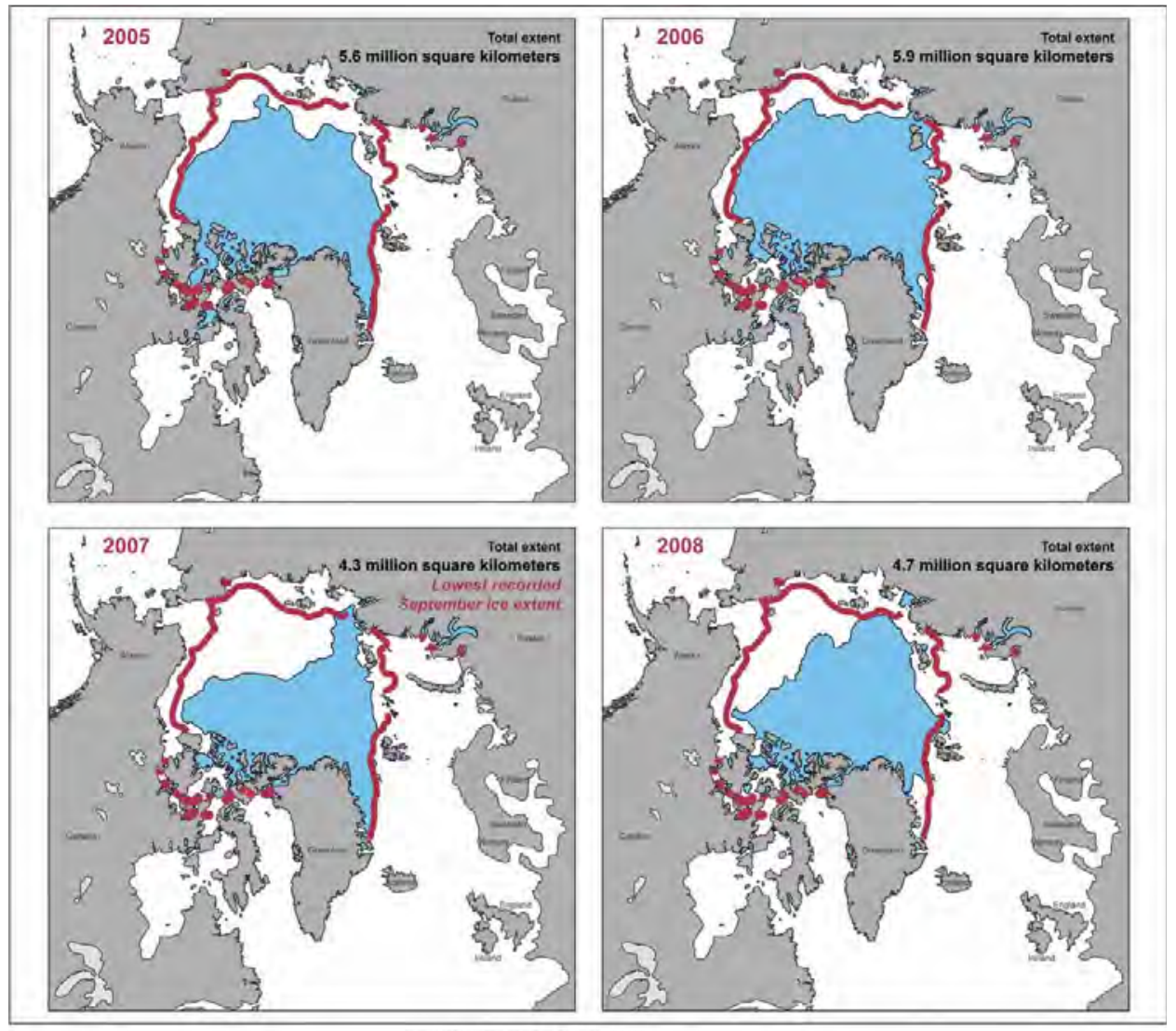

Source: National Snow and Ice Data Cemes 
THE QUARTERLY JOURNAL

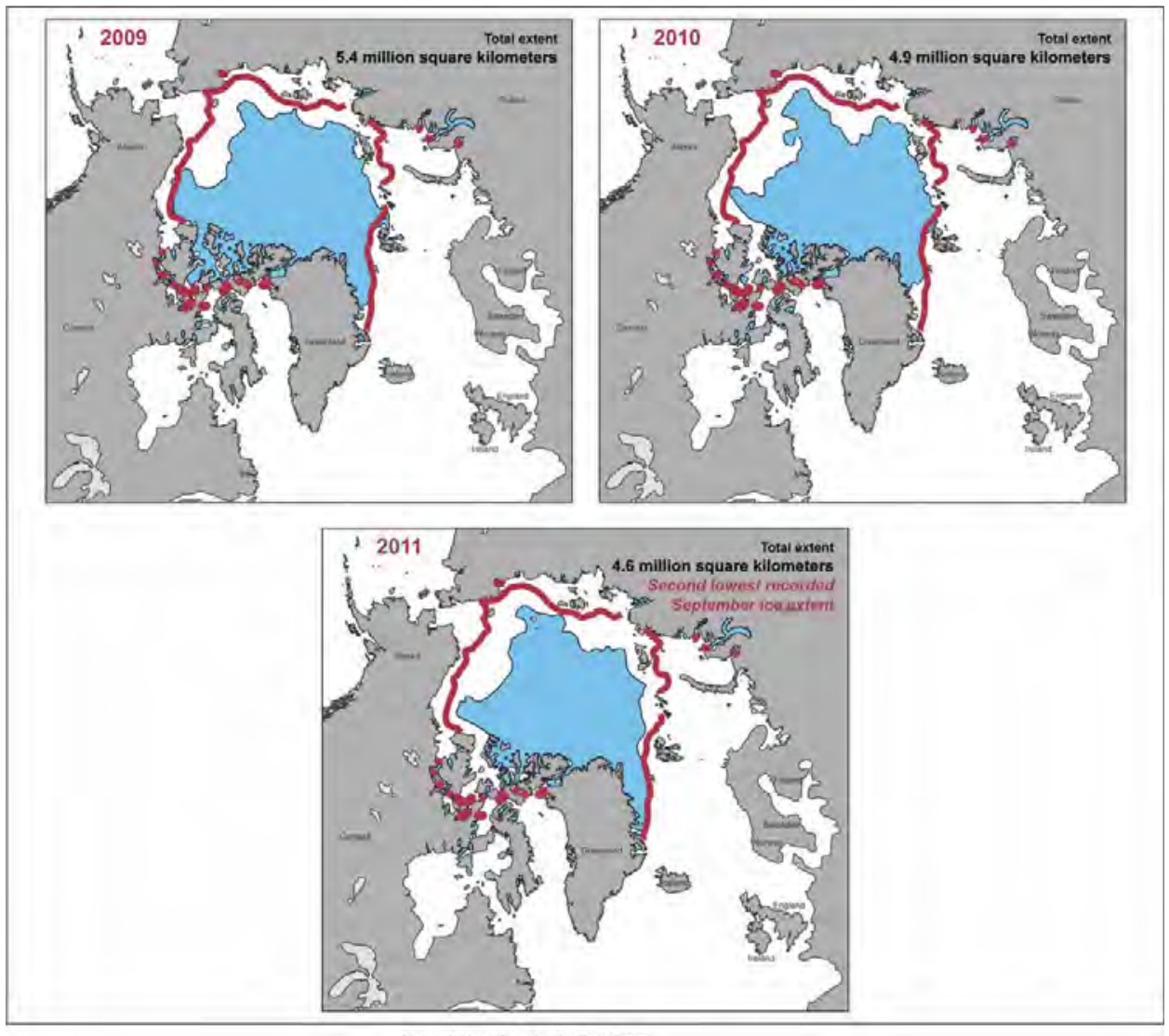

Source: National Snow and Ice Data Cemer. 


\title{
Appendix IV: GAO Contact and Staff Acknowledgments
}

\author{
GAO Contact
}

John H. Pendleton, (202) 512-3489 or pendletonj@gao.gov

Staff Acknowledgments

In addition to the contact named above, key contributors to this report were Suzanne Wren (Assistant Director), Susan Ditto, Nicole Harms, Timothy Persons, Steven Putansu, Frank Rusco, Jodie Sandel, Amie Steele, and Esther Toledo.

Stephen L. Caldwell (Director), Dawn Hoff (Assistant Director), and Elizabeth Kowalewski contributed expertise on the Department of Homeland Security and Coast Guard.

\section{Related GAO Products}

Coast Guard: Observations on Arctic Requirements, Icebreakers, and Coordination with Stakeholders, GAO-12-254T (Washington, D.C.: 1 December 2011); available at www.gao.gov/products/GAO-12-254T.

Climate Change Adaptation: Federal Efforts to Provide Information Could Help Government Decision Making, GAO-12-238T (Washington, D.C.: 16 November 2011); available at www.gao.gov/products/GAO-12-238T.

Coast Guard: Action Needed as Approved Deepwater Program Remains Unachievable, GAO-12-101T (Washington, D.C.: 4 October 2011); available at www.gao.gov/ products/GAO-12-101T.

Polar Satellites: Agencies Need to Address Potential Gaps in Weather and Climate Data Coverage, GAO-11-945T (Washington, D.C.: 23 September 2011); available at www.gao.gov/products/GAO-11-945T.

Climate engineering: Technical status, future directions, and potential responses, GAO-11-71 (Washington, D.C.: 28 July 2011); available at www.gao.gov/products/ GAO-11-71.

Homeland Defense: Actions Needed to Improve DOD Planning and Coordination for Maritime Operations, GAO-11-661 (Washington, D.C.: 23 June 2011); available at www.gao.gov/products/GAO-11-661.

Intelligence, Surveillance, and Reconnaissance: DOD Needs a Strategic, Risk-Based Approach to Enhance Its Maritime Domain Awareness, GAO-11-621 (Washington, D.C.: 20 June 2011); available at www.gao.gov/products/GAO-11-621.

Defense Management: Perspectives on the Involvement of the Combatant Commands in the Development of Joint Requirements, GAO-11-527R (Washington, D.C.: 20 May 2011); available at www.gao.gov/products/GAO-11-527R. 
Coast Guard: Observations on Acquisition Management and Efforts to Reassess the Deepwater Program, GAO-11-535T (Washington, D.C.: 13 April 2011); available at www.gao.gov/products/GAO-11-535T.

Defense Management: Additional Cost Information and Stakeholder Input Needed to Assess Military Posture in Europe, GAO-11-131 (Washington, D.C.: 3 February 2011); available at www.gao.gov/products/GAO-11-131.

Coast Guard: Efforts to Identify Arctic Requirements Are Ongoing, but More Communication about Agency Planning Efforts Would Be Beneficial, GAO-10-870 (Washington, D.C.: 15 September 2010); available at www.gao.gov/products/GAO-10-870.

Environmental Satellites: Strategy Needed to Sustain Critical Climate and Space Weather Measurements, GAO-10-456 (Washington, D.C.: 27 April 2010); available at www.gao.gov/products/GAO-10-456.

Interagency Collaboration: Key Issues for Congressional Oversight of National Security Strategies, Organizations, Workforce, and Information Sharing, GAO-09-904SP (Washington, D.C.: 25 September 2009); available at www.gao.gov/products/GAO-09904SP.

Defense Acquisitions: DOD's Requirements Determination Process Has Not Been Effective in Prioritizing Joint Capabilities, GAO-08-1060 (Washington, D.C.: 25 September 2008); available at www.gao.gov/products/GAO-08-1060.

Coast Guard: Condition of Some Aids-to-Navigation and Domestic Icebreaking Vessels Has Declined; Effect on Mission Performance Appears Mixed, GAO-06-979 (Washington, D.C.: 22 September 2006); available at www.gao.gov/products/GAO-06979.

Executive Guide: Effectively Implementing the Government Performance and Results Act, GAO/GGD-96-118 (Washington, D.C.: June 1996); available at www.gao.gov/ products/GGD-96-118. 